ISSN 2775-0485

\title{
SURVEI PERUBAHAN PENGGUNAAN LAHAN MENGGUNAKAN METODE UNIT LAHAN DI KECAMATAN CIBATU, KABUPATEN GARUT, JAWA BARAT
}

\section{Land Use Change Survey Using Land Unit Method in Cibatu Sub-District, Garut District, Jawa Barat}

\author{
Ardli Swardana ${ }^{1)}$, Rama Januar ${ }^{2)}$, Arifin Mansyur ${ }^{2)}$, Fauzi Ismail ${ }^{2)}$, Resta Ginanjar \\ Merdeka $^{2)}$ \\ 1) Dosen Fakultas Pertanian, Universitas Garut \\ ${ }^{2)}$ Mahasiswa Fakultas Pertanian, Universitas Garut \\ J1. Raya Samarang No.52A, Tarogong Kaler, Kabupaten Garut, Jawa Barat 44151 \\ e-mail : ardli@uniga.ac.id
}

\begin{abstract}
Abstrak
Perubahan penggunaan lahan merupakan fenomena yang banyak terjadi di berbagai tempat. Salah satu faktor pemicunya adalah adanya kebutuhan lahan. Kecamatan Cibatu merupakan bagian dari Kabupaten Garut dimana diduga terdapat kondisi perubahan penggunaan lahan. Penelitian dilakukan pada Bulan September - November 2020 yang berlokasi di seluruh area Kecamatan Cibatu. Metode yang digunakan di dalam penelitian ini adalah metode analisis spasial dan metode survey. Metode analisis spasial yang digunakan adalah tumpang susun data spasial, sedangkan metode survey yang digunakan adalah groundcheck. Metode analisis spasial digunakan untuk menyusun unit-unit lahan untuk memudahkan pengambilan sampel. Jumlah sampel yang digunakan dalam penelitian ini adalah 21 sampel. Hasil penelitian menunjukkan bahwa terdapat perubahan penggunaan lahan sawah di Kecamatan Cibatu dari sawah menjadi permukiman. Dari 21 sampel lokasi yang disurvey, hanya 1 sampel yang teridentifikasi telah terjadi perubahan penggunaan lahan. Hal ini dapat dikatakan bahwa laju perubahan penggunaan lahan di Kecamatan Cibatu tidak signifikan. Selain itu, metode unit lahan mampu digunakan untuk mempermudah penentuan sampel untuk identifikasi perubahan penggunaan lahan.
\end{abstract}

Kata Kunci : Perubahan Penggunaan Lahan, Survei, Unit Lahan

\section{ABSTRACT}

Land use change is a phenomenon that occurs in many places. One of the triggering factors is the need for land. Cibatu Subdistrict is part of Garut Regency where it is suspected that there are changes in land use conditions. The research was conducted in September - November 2020, which are located in the entire Cibatu Subdistrict area. The method used in this research is spatial analysis method and survey method. The method of spatial analysis used was overlapping spatial data, while the survey method used was groundcheck. The spatial analysis method is used to arrange land units to facilitate sampling. The number of samples used in this study were 21 samples. The results showed that there was a change in the use of rice fields in Cibatu District from 
rice fields to settlements. Of the 21 sample locations surveyed, only 1 sample was identified that a change in land use had occurred. It can be said that the rate of land use change in Cibatu District is not significant. In addition, the land unit method can be used to facilitate sampling for identification of land use change.

Keywords: landuse change, survey, land unit

\section{Pendahuluan}

Penggunaan lahan erat kaitannya dengan aktivitas manusia. Aktivitas manusia dalam mengelola atau memanfaatkan suatu lahan untuk penggunaan tertentu disebut dengan penggunaan lahan. Dalam aktivitasnya, tidak jarang manusia melakukan modifikasi atau mengubah penggunaan lahan awal menjadi penggunaan lahan baru. Fenomena itu disebut dengan perubahan penggunaan lahan.

Perubahan penggunaan lahan saat ini sudah menjadi hal yang wajar terjadi di berbagai tempat. Faktor yang menyebabkan adanya perubahan penggunaan lahan ini utamanya didasari oleh kebutuhan masyarakat akan lahan karena efek dari kondisi pertambahan penduduk (Khadiyanto, 2005). Selain itu, perubahan penggunaan lahan juga dapat mencerminkan suatu fenomena pertumbuhan ekonomi di suatu wilayah (Chen, 2014).

Banyak metode yang dapat digunakan untuk mengidentifikasi perubahan penggunaan lahan di suatu wilayah. Salah satu metode yang dapat digunakan untuk melihat fenomena tersebut adalah menggunakan metode analisis spasial menggunakan Sistem Informasi Geografis (SIG) (Utami, et. al 2018). SIG merupakan rangkaian kegiatan pengumpulan, penataan, pengolahan, dan penganalisisan data/fakta spasial sehingga diperoleh informasi spasial untuk dapat menjawab atau menyelesaikan suatu masalah dalam ruang muka bumi tertentu (Sajiman, 2006).

Penggunaan metode ini untuk keperluan deteksi perubahan penggunaan lahan dapat diarahkan ke pembentukan unit-unit lahan untuk penentuan lokasi yang perlu disurvey untuk melihat perubahan penggunaan lahan. Unit lahan sendiri didefinisikan sebagai sebidang lahan yang mempunyai kondisi lahan dalam bentuk sama tetapi mempunyai karakteristik yang berbeda-beda. Unit lahan sendiri diturunkan dari beberapa data spasial. Sifat homogen pada unit lahan ini akan memudahkan proses penelitian karena unit-unit lahan yang sama akan diwakili atau dikelompokkan menjadi satu unit tersendiri (Budiarta, 2014).

Kecamatan Cibatu yang terletak di Kabupaten Garut merupakan salah satu kecamatan yang diduga mengalami perubahan penggunaan lahan. Hal ini dikarenakan perkembangan fasilitas dan aksesibilitas di kecamatan tersebut yang dinilai mengalami perkembangan. Tulisan ini bertujuan untuk melihat laju perubahan penggunaan lahan dengan menggunakan metode unit lahan.

\section{Metodologi}

Penelitian ini dilakukan di seluruh area di Kecamatan Cibatu, Kabupaten Garut, Provinsi Jawa Barat. Waktu penelitian ini adalah pada Bulan September - November 2020. Metode yang digunakan pada penelitian ini adalah analisis spasial menggunakan software Sistem Informasi Geografis (SIG). Data yang digunakan pada penelitian ini 
berupa data spasial berupa data penutupan lahan tahun 2018, data curah hujan tahun 1998 - 2010 dan data formasi geologi skala 1:250.000 Lembar Garut-Pamengpeuk tahun 1992.

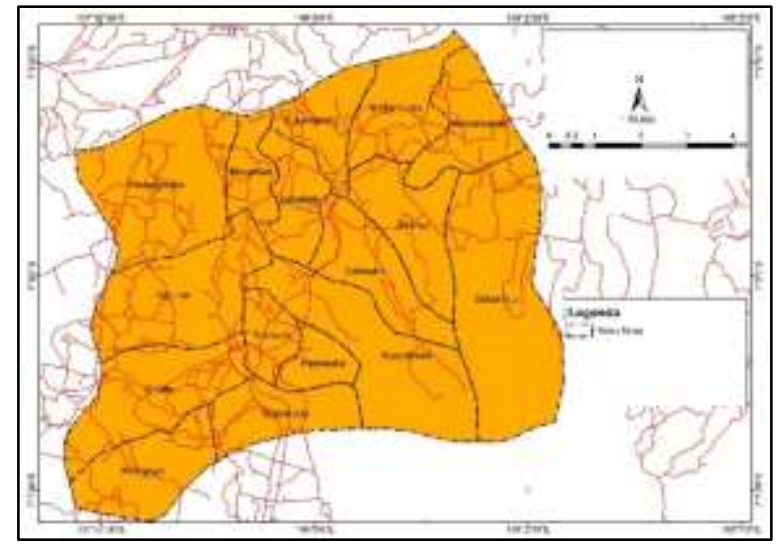

Gambar 1. Peta Lokasi Penelitian

Dari ketiga data spasial tersebut kemudian dilakukan tumpang susun (overlay) (Bielecka, 2020), sehingga diperoleh beberapa satuan lahan/unit lahan. Setelah diperoleh unit-unit lahan tersebut, kemudian ditentukan 21 plot sampel yang lokasinya tersebar di Kecamatan Cibatu. Plot sampel tersebut kemudian divisualisasikan sebagai peta tentatif yang kemudian digunakan sebagai peta kerja di lapangan. Tehnik pengamatan di lapangan adalah teknik survey, yaitu groundcheck terhadap perubahan penggunaan lahan yang terdapat di lokasi penelitian. Setelah proses survey selesai, kemudian dilakukan koreksi terhadap peta kerja, sehingga diperoleh data identifikasi perubahan penggunaan lahan yang didasarkan kepada unit-unit lahan yang telah digunakan.

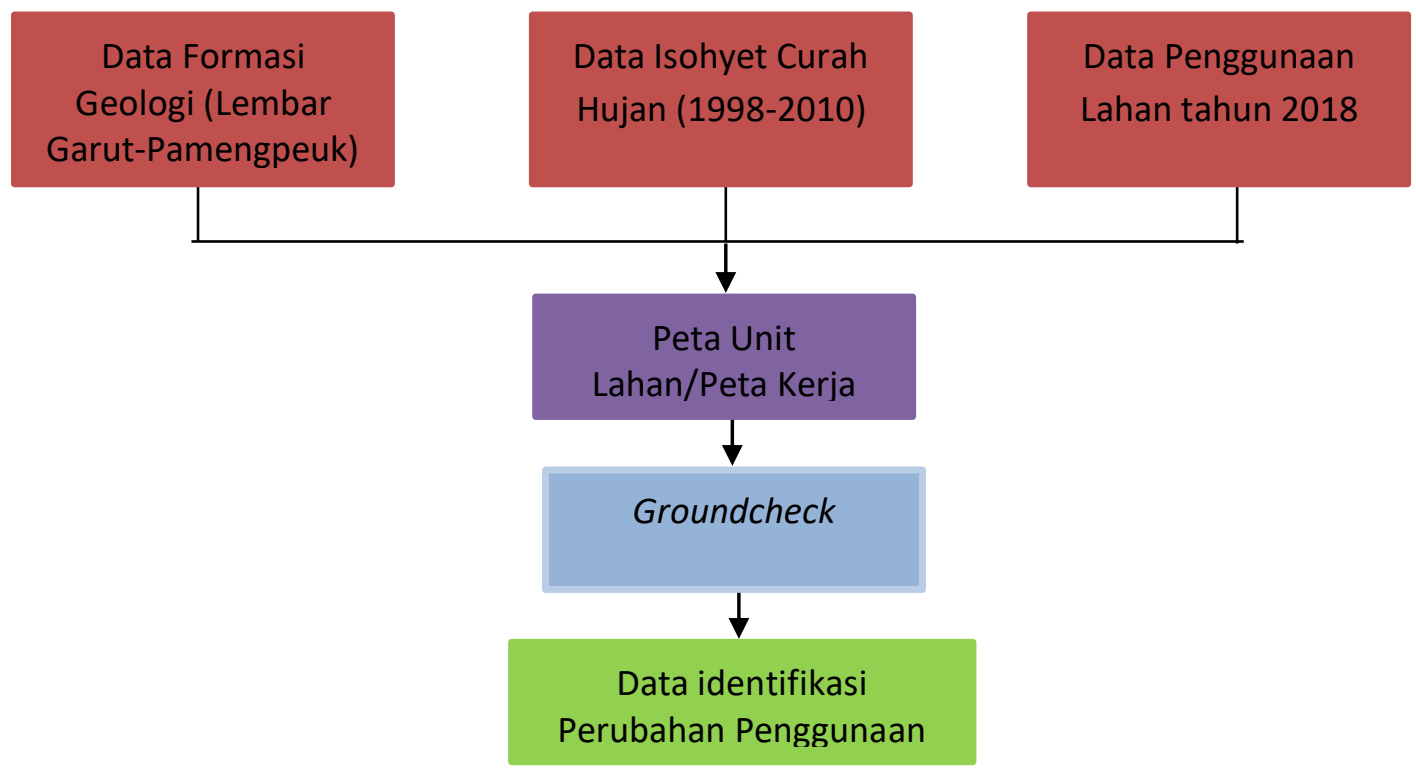

Gambar 2. Diagram Penelitian

\section{Hasil dan Pembahasan}




\section{PEMBENTUKAN UNIT LAHAN}

Pembentukan unit lahan di dalam penelitian ini menggunakan 3 data spasial, yaitu data curah hujan tahun 1998 - 2010, data penggunaan lahan tahun 2018, dan data formasi geologi. Berikut akan diulas tentang kondisi ketiga data tersebut di lokasi penelitian.

\section{Curah Hujan}

Data curah hujan yang digunakan mulai dari tahun 1998-2010. Pengolahan data curah hujan ini dilakukan dengan metode isohyet. Metode isohyet ini merupakan metode yang dipakai untuk menentukan atau menaksir curah hujan rata-rata di suatu wilayah berdasarkan sebaran stasiun curah hujan yang tidak merata (Ria, 2008).

Berdasarkan pengolahan data curah hujan, diperoleh 2 besaran curah hujan di Kecamatan Cibatu, yaitu 2200-2500 mm/tahun dan 2500-2800 mm/tahun. Gambaran kondisi curah hujan ditunjukkan pada Gambar 3 dan Tabel 1.

Tabel 1. Sebaran curah hujan di lokasi penelitian

\begin{tabular}{clr} 
No & \multicolumn{1}{c}{ Curah Hujan (mm/tahun) } & Luas (ha) \\
\hline 1 & $2200-2500$ & $4.263,76$ \\
2 & $2500-2800$ & $3.490,13$ \\
& Total & $\mathbf{7 . 7 5 3 , 8 9}$
\end{tabular}

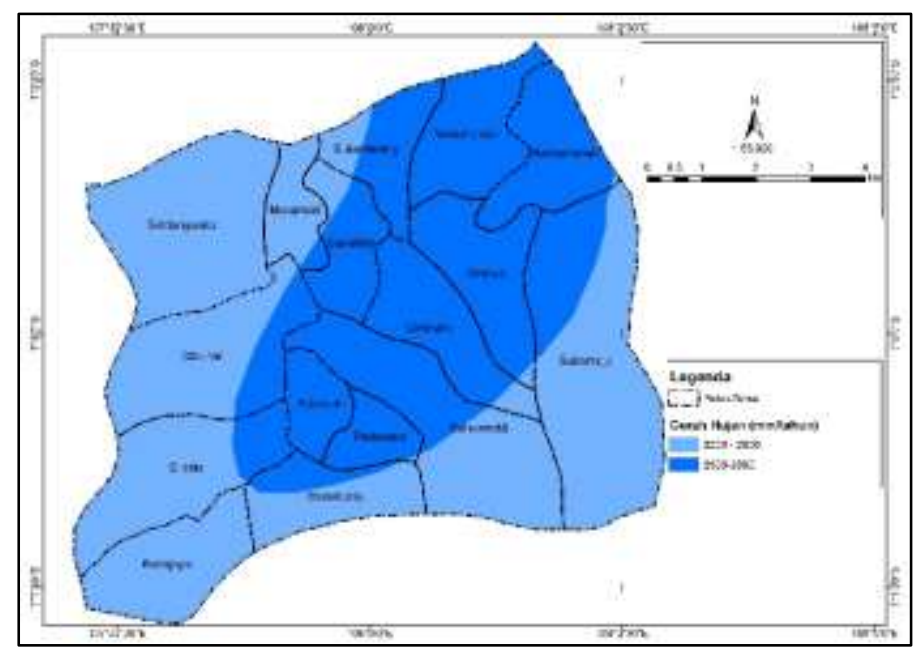

Gambar 3. Peta sebaran curah hujan Kecamatan Cibatu

Berdasarkan Tabel 1 dan Gambar 2 terlihat bahwa Kecamatan Cibatu didominasi oleh curah hujan dengan besaran 2.200-2500 mm/tahun, yaitu seluas 4.263,76 ha. Wilayah yang mempunyai curah hujan ini tersebar di sebelah barat, selatan dan timur, sedangkan sisanya adalah wilayah yang mempunyai besaran curah hujan 2500-2800 $\mathrm{mm} /$ tahun yang wilayahnya tersebar di sebelah utara hingga tengah dengan luas wilayah sebesar 3.490,13 ha. Daerah yang mempunyai curah hujan 2500-2800 mm/tahun ini di lapangannya merupakan areal berupa dataran tinggi.

\section{Formasi Geologi}


Berdasarkan identifikasi formasi geologi, Kecamatan Cibatu terdiri dari 6 formasi geologi, yaitu aluvium, batuan gunungapi muda, endapan rempah lepas gunungapi muda tak terurai, hasil gunungai tua tak teruraikan, tuf Banten, dan Tuf batu apung dan breksi. Sebaran dan luasan formasi geologi di Kecamatan Cibatu ditunjukkan pada Tabel 2 dan Gambar 4.

Tabel 2. Sebaran formasi geologi di lokasi penelitian

\begin{tabular}{clr} 
No & \multicolumn{1}{c}{ Formasi Geologi } & Luas (ha) \\
\hline 1 & Aluvium & 412,13 \\
2 & Batuan Gunungapi Muda & 81,63 \\
3 & Endapan Rempah Lepas Gunungapi Muda Tak Terurai & 999,57 \\
4 & Hasil Gunungapi Tua Tak Teruraikan & 151,50 \\
5 & Tuf Banten & $3.107,46$ \\
6 & Tuf Batu apung dan Breksi & $3.001,59$ \\
& Total & $\mathbf{7 . 7 5 3 , 8 9}$
\end{tabular}

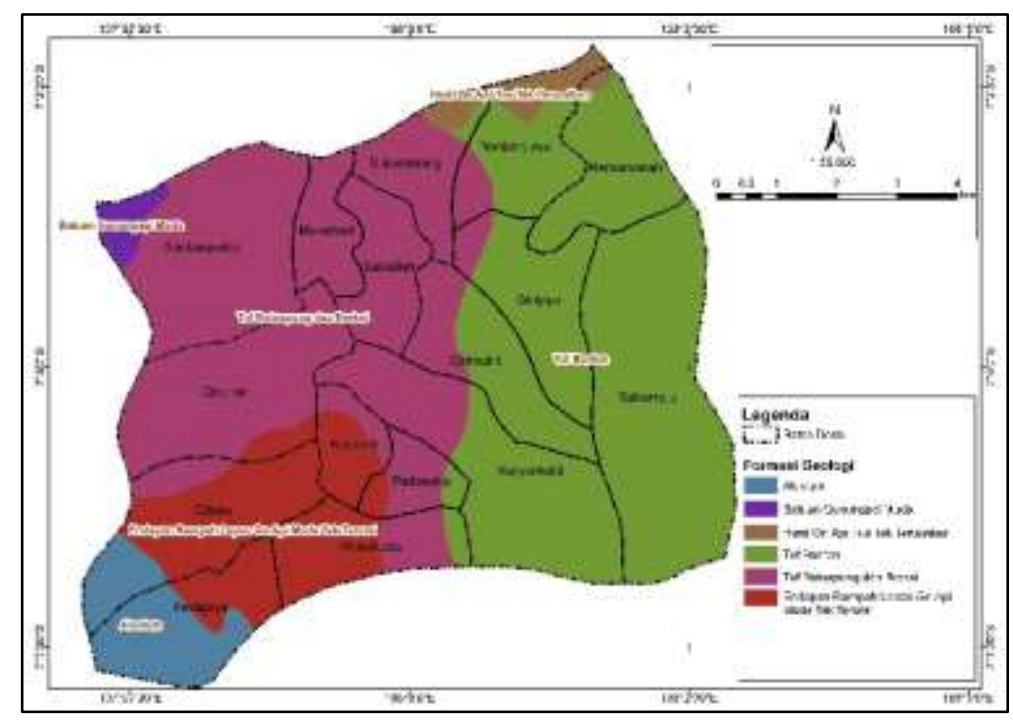

Gambar 4. Peta sebaran formasi geologi Kecamatan Cibatu

Berdasarkan identifikasi dari data geologi, formasi geologi di Kecamatan Cibatu yang mendominasi lokasi penelitian adalah Tuf Banten seluas 3.107,46 ha, sedangkan yang terkecil adalah formasi batuan gunungapi muda yaitu seluas 81,63 ha. Dari hasil identifikasi formasi geologi ini diketahui hanya formasi geologi aluvium saja yang tidak terdapat pengaruh atau hubungan vulkanik, sedangkan kelima formasi geologi yang lainnya terdaoat hubungan atau pengaruh dari aktivitas vulkanik.

\section{Penggunaan Lahan}

Hasil identifikasi data penggunaan lahan tahun 2018, penggunaan lahan di Kecamatan Cibatu terdiri dari 6 jenis penggunaan lahan. Keenam jenis penggunaan lahan tersebut diantaranya Hutan Tanaman Industri (HTI), perkebunan, permukiman, pertanian lahan kering, pertanian lahan kering bercampur semak dan sawah. Sebaran penggunaan lahan di Kecamatan Cibatu ditinjukkan pada Tabel 3 dan Gambar 5. 
Tabel 3. Sebaran formasi geologi di lokasi penelitian

\begin{tabular}{clr} 
No & \multicolumn{1}{c}{ Penggunaan Lahan } & Luas (ha) \\
\hline 1 & Hutan Tanaman Industri (HTI) & $1.172,59$ \\
2 & Perkebunan & 42,80 \\
3 & Permukiman & 371,21 \\
4 & Pertanian Lahan Kering & $1.693,24$ \\
5 & Pertanian Lahan Kering Bercampur dengan Semak & $2.012,10$ \\
6 & Sawah & $2.461,95$ \\
& Total & $\mathbf{7 . 7 5 3 , 8 9}$
\end{tabular}

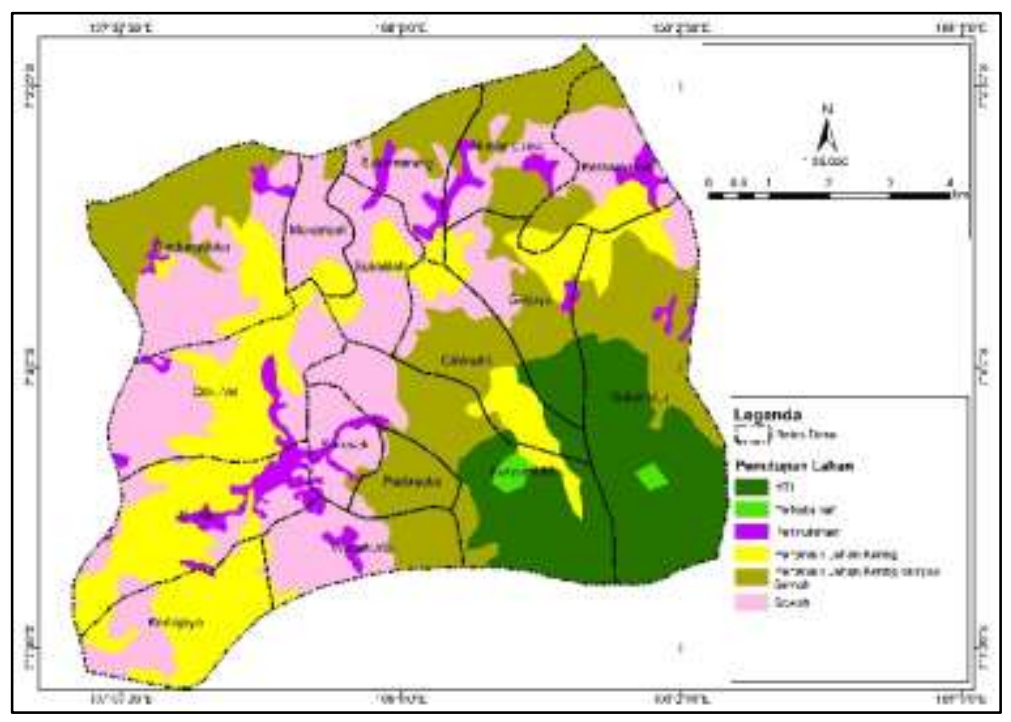

Gambar 5. Peta sebaran penggunaan lahan tahun 2018 Kecamatan Cibatu

Hasil identifikasi penggunaan lahan di Kecamatan Cibatu diperoleh hasil bahwa penggunaan lahan sawah merupakan penggunaan lahan terbesar di Kecamatan Cibatu, yaitu seluas $2.461,95$ ha. Hal ini sejalan dengan mata pencaharian masyarakatnya yang sebagian besar adalah petani. Penggunaan lahan terkecil di Kecamatan Cibatu adalah Perkebunan yang terdapat di Desa Sukamaju dan Karyamukti dengan total luasan sebesar 42,80 ha.

Setelah dilakukan identifikasi dari data spasial tersebut kemudian dilakukan penentuan unit-unit lahan untuk mempermudah penentuan pengambilan sampel. Pembuatan unit lahan dilakukan dengan cara melakukan overlay pada ketiga data di atas. Selain unit lahan, juga dilakukan penetapan sampel untuk identifikasi perubahan penggunaan lahan berdasarkan unit lahan yang telah dibuat. Namun demikian, tidak semua unit lahan dilakukan survey mengingat luasan areal yang dinilai terlalu kecil dan dianggap tidak signifikan dalam perubahannya Berikut hasil unit lahan yang diperoleh dari kombinasi ketiga data spasial yang digunakan sebagaimana ditunjukkan pada Tabel 4.

Tabel 4. Unit lahan di lokasi penelitian dan penentuan lokasi sampel

\begin{tabular}{crlll} 
No & $\begin{array}{r}\text { Curah } \\
\text { Hujan }\end{array}$ & \multicolumn{1}{c}{ Formasi Geologi } & \multicolumn{1}{c}{ Penggunaan Lahan } & \multicolumn{1}{c}{$\begin{array}{c}\text { Plot } \\
\text { Sampel }\end{array}$} \\
\hline 1 & $2200-2500$ & aluvium & Permukiman & \\
2 & $2200-2500$ & aluvium & Pertanian Lahan Kering &
\end{tabular}




\begin{tabular}{|c|c|c|c|c|}
\hline No & $\begin{array}{l}\text { Curah } \\
\text { Hujan }\end{array}$ & Formasi Geologi & Penggunaan Lahan & $\begin{array}{c}\text { Plot } \\
\text { Sampel }\end{array}$ \\
\hline 3 & $2200-2500$ & aluvium & Sawah & $\mathrm{T} 8$ \\
\hline 4 & $2200-2500$ & Batuan Gunungapi Muda & Pertanian Lahan Kering & $\mathrm{T} 1$ \\
\hline 5 & $2200-2500$ & $\begin{array}{l}\text { Endapan Rempah Lepas } \\
\text { Gn.Api Muda Tak Terurai }\end{array}$ & $\begin{array}{l}\text { Bercampur dengan Semak } \\
\text { Permukiman }\end{array}$ & \\
\hline 6 & $2200-2500$ & $\begin{array}{l}\text { Endapan Rempah Lepas } \\
\text { Gn.Api Muda Tak Terurai }\end{array}$ & Pertanian Lahan Kering & T6 \\
\hline 7 & $2200-2500$ & $\begin{array}{l}\text { Endapan Rempah Lepas } \\
\text { Gn.Api Muda Tak Terurai }\end{array}$ & Sawah & $\mathrm{T} 7$ \\
\hline 8 & $2200-2500$ & Tuf Banten & HTI & T16, T19 \\
\hline 9 & $2200-2500$ & Tuf Banten & Perkebunan & T17 \\
\hline 10 & $2200-2500$ & Tuf Banten & Permukiman & \\
\hline 11 & $2200-2500$ & Tuf Banten & Pertanian Lahan Kering & \\
\hline 12 & $2200-2500$ & Tuf Banten & $\begin{array}{l}\text { Pertanian Lahan Kering } \\
\text { Bercampur dengan Semak }\end{array}$ & \\
\hline 13 & $2200-2500$ & Tuf Banten & Sawah & \\
\hline 14 & $2200-2500$ & Tuf Batu apung dan breksi & Permukiman & \\
\hline 15 & $2200-2500$ & Tuf Batu apung dan breksi & Pertanian Lahan Kering & T4 \\
\hline 16 & $2200-2500$ & Tuf Batu apung dan breksi & $\begin{array}{l}\text { Pertanian Lahan Kering } \\
\text { Bercampur dengan Semak }\end{array}$ & $\mathrm{T} 2, \mathrm{~T} 21$ \\
\hline 17 & $2200-2500$ & Tuf Batu apung dan breksi & Sawah & T3, T5 \\
\hline 18 & $2500-2800$ & $\begin{array}{l}\text { Endapan Rempah Lepas } \\
\text { Gn.Api Muda Tak Terurai }\end{array}$ & Permukiman & \\
\hline 19 & $2500-2800$ & $\begin{array}{l}\text { Endapan Rempah Lepas } \\
\text { Gn.Api Muda Tak Terurai }\end{array}$ & Pertanian Lahan Kering & \\
\hline 20 & $2500-2800$ & $\begin{array}{l}\text { Endapan Rempah Lepas } \\
\text { Gn.Api Muda Tak Terurai }\end{array}$ & $\begin{array}{l}\text { Pertanian Lahan Kering } \\
\text { Bercampur dengan Semak }\end{array}$ & \\
\hline 21 & $2500-2800$ & $\begin{array}{l}\text { Endapan Rempah Lepas } \\
\text { Gn.Api Muda Tak Terurai }\end{array}$ & Sawah & T9 \\
\hline 22 & $2500-2800$ & $\begin{array}{l}\text { Hasil Gn.Api Tua Tak } \\
\text { Teruraikan }\end{array}$ & $\begin{array}{l}\text { Pertanian Lahan Kering } \\
\text { Bercampur dengan Semak }\end{array}$ & T12 \\
\hline 23 & $2500-2800$ & $\begin{array}{l}\text { Hasil Gn.Api Tua Tak } \\
\text { Teruraikan }\end{array}$ & Sawah & \\
\hline 24 & $2500-2800$ & Tuf Banten & HTI & \\
\hline 25 & $2500-2800$ & Tuf Banten & Perkebunan & \\
\hline 26 & $2500-2800$ & Tuf Banten & Permukiman & \\
\hline 27 & $2500-2800$ & Tuf Banten & Pertanian Lahan Kering & $\mathrm{T} 18, \mathrm{~T} 20$ \\
\hline 28 & $2500-2800$ & Tuf Banten & $\begin{array}{l}\text { Pertanian Lahan Kering } \\
\text { Bercampur dengan Semak }\end{array}$ & T15 \\
\hline 29 & $2500-2800$ & Tuf Banten & Sawah & T14 \\
\hline 30 & $2500-2800$ & Tuf Batu apung dan breksi & Permukiman & \\
\hline 31 & $2500-2800$ & Tuf Batu apung dan breksi & Pertanian Lahan Kering & \\
\hline 32 & $2500-2800$ & Tuf Batu apung dan breksi & $\begin{array}{l}\text { Pertanian Lahan Kering } \\
\text { Bercampur dengan Semak }\end{array}$ & $\mathrm{T} 10$ \\
\hline 33 & $2500-2800$ & Tuf Batu apung dan breksi & Sawah & $\mathrm{T} 1, \mathrm{~T} 13$ \\
\hline
\end{tabular}

Berdasarkan identifikasi unit lahan dan penetapan plot sampel, diketahui bahwa plot sampel hanya berada pada 16 unit lahan saja. Hal ini disebabkan luasan dari area sampel pada peta terlalu sempit dan penetapan sampel berdasarkan keterwakilan lokasi area. 


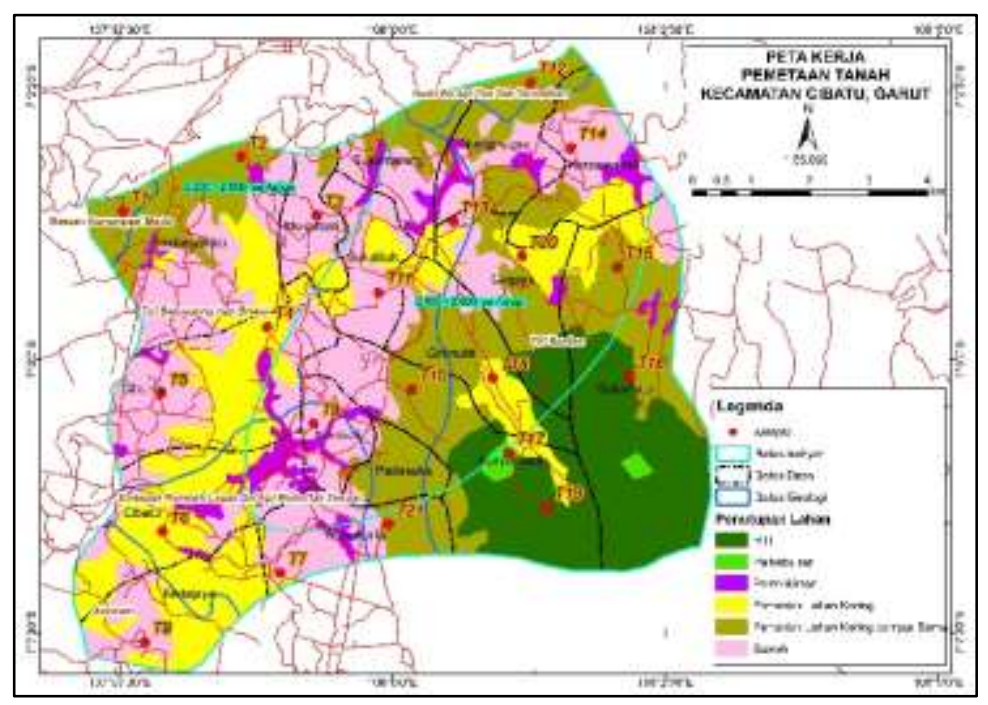

Gambar 6. Peta titik sampel

\section{Identifikasi Perubahan Penggunaan Lahan}

Identifikasi perubahan penggunaan lahan diperoleh dari pencocokan hasil identifikasi data penggunaan lahan tahun 2018 dengan perkembangan penggunaan lahan pada tahun 2020. Metode yang dilakukan dengan cara survey secara groundcheck dari titik sampel yang telah ditetapkan. Berdasarkan hasil groundcheck yang dilakukan, diperoleh data perubahan penggunaan lahan seperti ditunjukkan pada Tabel 5.

Tabel 5 terlihat bahwa penggunaan lahan yang diperoleh dari data penggunaan lahan 2018 tidak banyak mengalami perubahan berdasarkan hasil survey pada tahun 2020 . Dari ke-21 titik sampel yang diamati, hanya terdapat 1 titik sampel, yaitu T14 yang telah beralih penggunaan lahannya. Perubahan penggunaan lahan yang terjadi pada T14 adalah sawah menjadi permukiman. Lokasi T14 ini berada di Kp Ciorai Tengah, Desa Kersamanah, Kecamatan Cibatu.

Tabel 5 Perbandingan data penggunaan lahan 2018 dengan hasil survey tahun 2020 di Kecamatan Cibatu

\begin{tabular}{|c|c|c|c|}
\hline No & Plot Sampel & $\begin{array}{c}\text { Data Penggunaan Lahan } \\
\text { tahun } 2018\end{array}$ & $\begin{array}{c}\text { Penggunaan Lahan Hasil Survey } \\
\text { tahun } 2020\end{array}$ \\
\hline \multirow[t]{2}{*}{1} & T1 & Pertanian Lahan $\quad$ Kering & $\begin{array}{lll}\text { Pertanian } & \text { Lahan } & \text { Kering }\end{array}$ \\
\hline & & Bercampur dengan Semak & Bercampur dengan Semak \\
\hline 2 & $\mathrm{~T} 2$ & $\begin{array}{l}\text { Pertanian Lahan Kering } \\
\text { Bercampur dengan Semak }\end{array}$ & $\begin{array}{l}\text { Pertanian Lahan Kering } \\
\text { Bercampur dengan Semak }\end{array}$ \\
\hline 3 & $\mathrm{~T} 3$ & Sawah & Sawah \\
\hline 4 & T4 & Pertanian lahan kering & Pertanian lahan kering \\
\hline 5 & T5 & Sawah & Sawah \\
\hline 6 & T6 & Pertanian lahan kering & Pertanian lahan kering \\
\hline 7 & $\mathrm{~T} 7$ & Sawah & Sawah \\
\hline 8 & $\mathrm{~T} 8$ & Sawah & Sawah \\
\hline 9 & T9 & Sawah & Sawah \\
\hline \multirow[t]{2}{*}{10} & $\mathrm{~T} 10$ & Pertanian Lahan Kering & Pertanian Lahan Kering \\
\hline & & Bercampur dengan Semak & Bercampur dengan Semak \\
\hline
\end{tabular}




\begin{tabular}{|c|c|c|c|}
\hline No & Plot Sampel & $\begin{array}{c}\text { Data Penggunaan Lahan } \\
\text { tahun } 2018\end{array}$ & $\begin{array}{c}\text { Penggunaan Lahan Hasil Survey } \\
\text { tahun } 2020\end{array}$ \\
\hline 11 & T11 & Sawah & Sawah \\
\hline \multirow[t]{2}{*}{12} & T12 & Pertanian Lahan Kering & Pertanian Lahan Kering \\
\hline & & Bercampur dengan Semak & Bercampur dengan Semak \\
\hline 13 & T13 & Sawah & Sawah \\
\hline 14 & T14 & Sawah & Permukiman \\
\hline \multirow[t]{2}{*}{15} & $\mathrm{~T} 15$ & Pertanian Lahan Kering & Pertanian Lahan Kering \\
\hline & & Bercampur dengan Semak & Bercampur dengan Semak \\
\hline 16 & T16 & HTI & HTI \\
\hline 17 & T17 & Perkebunan & Perkebunan \\
\hline 18 & $\mathrm{~T} 18$ & Pertanian lahan kering & Pertanian lahan kering \\
\hline 19 & T19 & HTI & HTI \\
\hline 20 & $\mathrm{~T} 20$ & Pertanian lahan kering & Pertanian lahan kering \\
\hline \multirow[t]{2}{*}{21} & $\mathrm{~T} 21$ & Pertanian Lahan Kering & Pertanian Lahan Kering \\
\hline & & Bercampur dengan Semak & Bercampur dengan Semak \\
\hline
\end{tabular}

Melihat fenomena perubahan penggunaan lahan menjadi sawah ini merupakan fenomena yang biasa terjadi. Kebutuhan masyarakat akan lahan menyebabkan terjadinya alih fungsi lahan. Alih fungsi lahan yang banyak terjadi adalah alih fungsi lahan sawah menjadi penggunaan lain, khususnya adalah permukiman.Menurut penelitian yang dilakukan oleh Swardana (2020) terlihat bahwa alih fungsi lahan sawah menjadi permukiman di Kabupaten Garut pada tahun 2009 - 2018 seluas 760,98 ha. Namun demikian, dilihat dari jumlah lokasi yang disurvey, terlihat hanya 1 dari 21 sampel yang mengalami perubahan penggunaan lahan. Hal ini berarti dapat dikatakan perubahan penggunaan lahan di Kecamatan Cibatu tidak terlalu besar perubahannya.

\section{Kesimpulan}

Berdasarkan hasil penelitian ini, dapat disimpulkan sebagai berikut:

1. Metode unit lahan memudahkan untuk teknik survey perubahan penggunaan lahan berdasarkan karakteristik lahan tersebut.di suatu lokasi.

2. Hasil survey menunjukkan bahwa di Kecamatan Cibatu, hanya ditemukan perubahan penggunaan lahan dari sawah menjadi permukiman.

3. Berdasarkan hasil survey, dapat dikatakan bahwa perubahan penggunaan lahan di Kecamatan Cibatu tidak terlalu signifkan.

\section{Daftar Pustaka}

Bielecka, E. (2020). GIS spatial analysis modeling for land use change. A bibliometric analysis of the intellectual base and trends. Geosciences (Switzerland). MDPI AG. https://doi.org/10.3390/geosciences10110421.

Budiarta, I. G. (2014). Analisis Kemampuan Lahan untuk Arahan Penggunaan Lahan pada Lereng Timur Laut Gunung Agung Kabupaten Karangasem-Bali. Media Komunikasi Geografi. 15(1):19-32.

Chen, J. (2014). GIS-based multi-criteria analysis for land use suitability assessment in City of Regina. Environmental Systems Research, 3(1), 13. https://doi.org/10.1186/2193-2697-3-13. 
Khadiyanto, P. (2005). Tata Ruang Berbasis pada Kesesuaian Lahan. Semarang: Universitas Diponegoro Press.

Ria, J. (2008). Identifikasi Aliran Permukaan di setiap Kecamatan DKI Jakarta Menggunakan Metode SCS. Bogor: IPB.

Sajiman. 2006. Modul Pelatihan sistem informasi Geografis SIG. Bandung:Informatika.

Swardana, A. (2020). Pemanfaatan Data SIG untuk Analisis Perubahan Penggunana Lahan Sawah di Kabupaten Garut (2009-2018). Prosiding Conference on Innovation and Application of Science and Technology (CIASTECH 2020) Universitas Widyagama Malang, 02 Desember 2020.

Utami, W., Artika, I. G. K., \& Arisanto, A. (2018). Aplikasi Citra Satelit Penginderaan Jauh untuk Percepatan Identifikasi Tanah Terlantar. BHUMI: Jurnal Agraria Dan Pertanahan, 4(1). https://doi.org/10.31292/jb.v4i1.2152. 